Original article. January-April 2018; 8(1):28-35. Received: 21/02/2017 Accepted: 20/07/2017.

http://dx.doi.org/10.21929/abavet2018.81.2

\title{
Reproducción y mortalidad de razas bovinas en clima subtropical de Argentina
}

Reproduction and mortality of cattle breeds in subtropical climate of Argentina

\author{
Juan Verdoljak' ${ }^{1}$ verdoljak.juan@inta.gob.ar, María Pereira1 pereira.maria@inta.gob.ar, Luis \\ Gándara ${ }^{1}$ gandara.luis@inta.gob.ar, Fabián Acosta ${ }^{1}$ acosta.fabian@inta.gob.ar, \\ Carolina Fernández-López ${ }^{1}$ fernandez.carolina@inta.gob.ar, Juan Martínez-González \\ jmartinez@docentes.uat.edu.mx
}

${ }^{1}$ Estación Experimental Agropecuaria Corrientes-Instituto Nacional de Tecnología Agropecuaria. Corrientes, Argentina. ${ }^{2}$ Universidad Autónoma de Tamaulipas-Facultad de Ingeniería y Ciencias. Ciudad Victoria, Tamaulipas, México. *Author responsible and correspondence: Juan Carlos Martínez González. Centro Universitario Adolfo López Mateos, Ciudad Victoria, Tamaulipas, México. CP. 87149.

\section{RESUMEN}

El ambiente tropical provoca bajos índices reproductivos en el ganado bovino, por lo tanto, el objetivo de la investigación fue evaluar el efecto del ambiente sobre los índices de reproducción bovina. La investigación se realizó en la Estación Experimental Agropecuaria (EEA) Corrientes, Argentina. Se analizaron los datos de 3,082 registros del hato; del año 1991 hasta el año 2009 de tres razas: Hereford (HR), Braford (BF) y Brahman $(\mathrm{BH})$. Se evaluaron dos variables: la primera, la pérdida de los productos a partir de su diagnóstico hasta el momento del parto (DP) y la segunda, inicia del día de su nacimiento hasta su destete en 205 d (PD). Para analizar los datos se realizó un diseño completamente al azar y un análisis de correlación. Las pérdidas se observaron durante la gestación para vacas $\mathrm{BH}$ y $\mathrm{BF}(\mathrm{P}<0.05)$, la humedad relativa no presentó efecto sobre la gestación y días al destete. Hubo correlación entre la humedad y la radiación con las vacas HR y $\mathrm{BF}$ que no se preñaron, las vacas $\mathrm{BH}$ no presentaron ninguna relación.

Palabras clave: Mortalidad, bovinos, eficiencia.

\section{ABSTRACTS}

Tropical environmental climate causes low reproductive rates in cattle, so the objective of the present study was to evaluate the possible effects of the climate on the reduction of the rates of bovine reproduction. The work was carried out in the Experimental Agriculture Station (EAS) in Corrientes, Argentina, where, 3,082 bovine herd records data were analyzed from 1991 to 2009, three breeds, Hereford (HR), Braford (BF) and Brahman (BH). It was evaluated the percentage of losses from the diagnosis of gestation until the delivery (DP) and from the delivery until the weaning to the $205 \mathrm{~d}$ (PD). Data were analyzed by analysis of variance in a completely randomized design and with an analysis of correlation. The greater losses $(P<0.05)$ were observed during the period of gestation for them cows $\mathrm{BH}$ and $\mathrm{BF}$, the humidity relative not presented difference $(P>0.05)$ between DP and PD. There was a correlation between the humidity and the radiation with the cows that were not in gestation (HR and BF), the cows $\mathrm{BH}$ not presented any relation.

Key words: Mortality, bovines, efficiency. 


\section{INTRODUCTION}

Reproductive indexes in cattle from tropical and subtropical regions are deficient, pregnancy rates can range from 45 to $55 \%$, with intervals of 18 months between births, and cow birth usually occurs for more than three years (Dobson and Smith, 2000). These productive indexes are affected by genetic factors such as: race, health problems, herd management and climatic factors as well as ambient temperature, relative humidity and solar radiation. In these conditions the reproductive performance of cattle depends on their adaptation to the environment (Montiel and Ahuja, 2005, Cordova et al., 2009).

Zebu cows and their calves are best adapted to environments with high temperatures; they are also more efficient using low quality fodder; without forgetting that they are highly resistant to external parasite infestations (López et al., 2004). However, the factors of greatest impact on the animals are the temperature of environment (Da Silva, 2006), water consumption and dry matter (Nienaber et al., 2003), in animals in open grazing systems (Lara et al., 2014).

Hansen et al. (2001) found that caloric stress $\left(41^{\circ} \mathrm{C}\right)$ decreased the proportion of embryos reaching the blastocyst stage. The susceptibility of embryos to the caloric stress diminishes as they advance in their development. Mansilla (2006) in Chile found that when the relative humidity exceeded $60 \%$ and the ambient temperature at $30{ }^{\circ} \mathrm{C}$ on the day of artificial insemination, there was depression in the gestation rate. Similar results are reported by Arias et al. (2008), who report that relative humidity and ambient temperature negatively affect reproductive activity.

There are several factors that expose cattle and generate stress, affecting the release of prostaglandins type PGF2 $\alpha$ that has luteolytic effects, aggravating infertility. Different authors, Escobar et al. (2005), Rivera-Suárez et al. (2006) and Román (2008) indicate that as the temperature of environment increases on the day of artificial insemination, the percentage of conception decreases. In addition, relative humidity has been associated with a low effectiveness to dissipate heat by sweating and breathing (Renaudeau, 2005; Da Silva, 2006).

The objective of this research was to evaluate the effects of breed and environment on losses, pre and postpartum, until weaning in calves from northern Argentina.

\section{MATERIAL AND METHODS}

The study was carried out at the Corrientes Agricultural Experiment Station (EEA according its acronyms in Spanish), where cattle production and reproductive behavior are monitored. The EEA of the National Institute of Agricultural Technology (INTA according its acronyms in Spanish) Corrientes, Argentina, is located in El Sombrerito at $27^{\circ} 40$ ' $08^{\prime \prime L S}$ and $58^{\circ} 45^{\prime} 44^{\prime \prime} \mathrm{LW}$, at $63 \mathrm{~m}$.

For the investigation, a total of 3,082 bovine herd bellies were analyzed from 1991 to 2009, from three breeds: Hereford (HE), Braford (BF) and Brahman (BH). The animals received annual sanitary management, based on a sanitary calendar that the INTA Institution recommends to the producers. The variables evaluated were the percentage of 
pregnancy (diagnosis of gestation), losses from diagnosis to delivery (PD) and weaning (PD) of the animals at 205 days.

During the years indicated, the data of: ambient temperature, relative humidity, wind speed and solar radiation were recorded daily in the EEA "Colonia Benítez" weather station located $30 \mathrm{~km}$ from the experimental unit; during the months of the service of rides to the cows (September to December). With this information the temperature-humidity index (ITH) was calculated, as established by Ingraham et al. (1974) with the following equation:

$$
\left.\mathrm{ITH}=\left(\left(1.8^{\circ} \mathrm{T}\right)+32\right)-(0.55-(0.55 \mathrm{HR} / 100))\left(\left(1.8^{\circ} \mathrm{T}\right)-26\right)\right)
$$

where:

ITH = temperature-humidity index;

$\mathrm{T}=$ temperature in degrees centigrade ${ }^{\circ} \mathrm{C}$;

$\mathrm{RH}=$ relative humidity .

The same equation was used to determine the degree of caloric stress to which the animals were subjected under environmental conditions. The data used for the statistical analysis were those indicated in the experimental period, subjected to an analysis of variance with a completely randomized design, using the program INFOSTAT (2014); to determine the effect of race on pregnancy rates and at what time the TP or PD variables recorded higher losses. Where statistical differences were observed, a comparison of means was made with the Tukey procedure $(P=0.05)$ and to correlate the effect of the climate a correlation was performed.

\section{RESULTS AND DISCUSSION}

\section{Loss of calves}

Loss of calves from gestation to parturition (DP), and calving at 205 days of weaning (Braford, Brahman and Hereford cows) are presented in Table 1. No statistical differences were observed between the breeds, but in PD the losses were significant in the Hereford breed $(P<0.05)$.

The diagnosis of gestation is performed at 42 days, using ultrasound or palpation to rule out embryonic death (Sartori, 2006). Studies conducted by Draghi et al. (2006) reported that there are many zoonotic causes (Brucella abortus, IBR, Leptospirosis, Campylobacter fetus, among others) that produce perinatal losses in the herd; which range from the time of fertilization to birth. However, these investigations conclude that in $40 \%$ of cases the etiology of the loss can not be determined. 
Table 1. Loss of calves from diagnosis of gestation to calving (PD) and calving at 205 days of weaning (PD) in Braford, Brahman and Hereford cows.

\begin{tabular}{lccc}
\hline & DP & PD & Pr $>$ F \\
\hline Braford & $6.31 \mathrm{a}$ & $3.78 \mathrm{~b}$ & 0.050 \\
Brahman & $7.65 \mathrm{a}$ & $3.37 \mathrm{~b}$ & 0.012 \\
Hereford & $5.37 \mathrm{a}$ & $5.32 \mathrm{a}$ & 0.096 \\
\hline & ${ }^{2}$ Different literals indicate significant differences $\mathrm{P}<0.05$
\end{tabular}

De Luca (2002) presented as causes of perinatal losses, those related to nutrition: energyprotein imbalance, hyperproteic rations, hyperammonemia, etc. In addition, it mentions that some plants have phytoestrogens (fusariosis, melilotus, and trifolium) and those susceptible to the Ergot fungus that produces ergotamines (Claviceps paspali) causing embryonic losses and thermal stress, as the most common causes. However, post-birth losses are due mostly to rodeo management and to those that occur from infections through the navel, which lead to motor problems compromising the calf's life. Similarly, the intake of colostrum in the first hours of calf life is critical, as it will provide defenses against infectious diseases (Faber et al., 2005; Arroyo et al., 2014).

Mortality losses in both DP and PD in Holstein cows were similar. These results may be due to the fact that the races are temperate and suffer in adverse climatic conditions of tropical climates. Environmental stressors such as heat and humidity cause low milk production, to problems such as eye cancer; without forgetting that HE cows are susceptible to endo and ectoparasites (Burrow et al., 2004).

\section{Percentage of pregnancy}

When analyzing the pregnancy rates, it was observed that the percentages of pregnancy had a correlation with the climatic variables in the HE and BR races. Radiation and relative humidity have a significant impact (Table 2). In the $\mathrm{BH}$ breed presented no corelation.

In Figure 1 it is observed that the greater number of cows not pregnant coincide with an increase in Radiation. For non-pregnant cows, early embryo losses ( $<42$ days) were considered as possible causes, since most of the pre-natal deaths occur during the first days after fertilization and during the implantation of the embryo in the uterus (Sartori, 2006).

Table 2. Correlation index between climatic variables and the percentage of pregnant wombs, during the natural mountaineering service from 1991 to 2009.

\begin{tabular}{cccc}
\hline Cimatic variables & Hereford & $\begin{array}{c}\text { Races } \\
\text { Braford }\end{array}$ & Brahman \\
\hline Radiación/Radiation & $46(p=0.047)^{*}$ & $53(p=0.020)^{*}$ & $25(p=0.303)$ \\
Humedad/Humidity & $-55(p=0.013)^{*}$ & $-51(p=0.024)^{*}$ & $-24(p=0.314)$ \\
Temperatura/Temperature & $23(p=0.354)$ & $16(p=0.514)$ & $21(p=0.381)$ \\
ITH ${ }^{* *}$ & $35(p=0.145)$ & $25(p=0.308)$ & $24(p=0.316)$ \\
Viento/Wind & $37(p=0.124)$ & $38(p=0.108)$ & $09(p=0.717)$ \\
Lluvia/Rain & $-05(p=0.825)$ & $-01(p=0.977)$ & $-01(p=0.978)$ \\
\hline \multicolumn{4}{c}{${ }^{*}$ degree of significance ${ }^{* *}$ Temperature-humidity index }
\end{tabular}




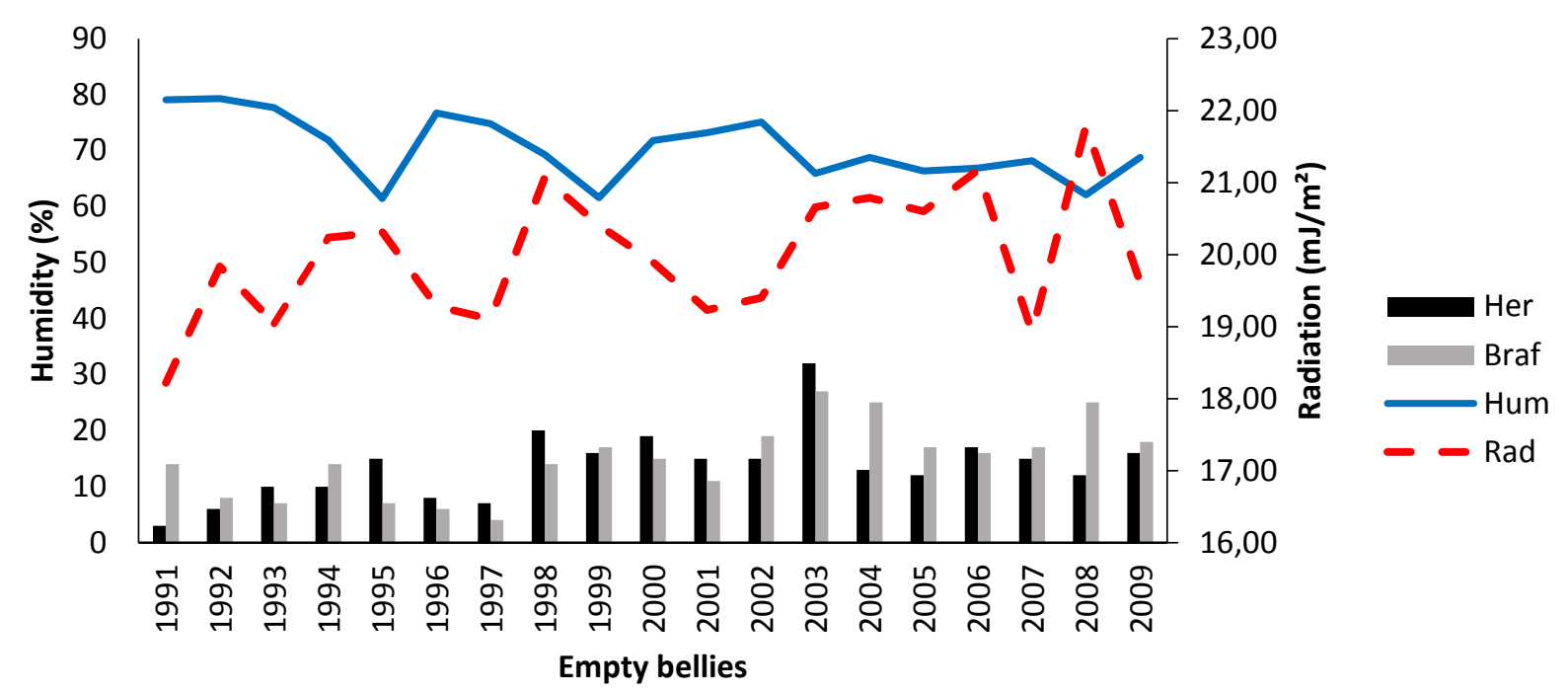

Figure 1. Effects of the climatic variables Radiation (Rad) and Humidity (Hum) on nonpregnancy in Hereford (Her) and Braford (Braf) cows, during 19 periods of natural mating services between the months of September and December of each year.

Uribe et al. (2001) determined that relative humidity and radiation are the main causes of decreased growth rates, reproductive failures and increased early embryo and fetal mortality. On the other hand, it is known that the color of the hair and the texture of the dark skin, absorb more heat; compared with the clear ones with equal environmental conditions (Col ba et al., 2002).

When evaluating the effect of relative humidity $(P<0.05)$, a negative relation was found with the number of empty cows. The direct effect on the animal may be due to the high humidity that prevents heat dissipation by sweating and breathing, causing thermal stress according to the reports of Renaudeau (2005).

Pires et al. (2011) reported that the animal's food is distributed in a preferential order, such as: basal metabolism, activity or work, growth, basic energy reserve, gestation, lactation, additional energy reserve, estrous cycle and onset of gestation; if there is an excess accumulates as a reserve of energy. This is why insufficient energy consumption is related to poor reproductive performance, resulting in long periods of postpartum anesthesia and low conception rate (Granja et al., 2012); even if the energy consumption normalizes postpartum.

Recent studies have found that nutritional deficiency during the last third of gestation interferes with the productive and reproductive performance of their offspring; highlighting the greater importance of prepartum nutrition than postpartum one, and may interfere with the programming of the fetus and consequently alter the productive and reproductive performance of the offspring (Granja et al., 2012). 


\section{CONCLUSION}

In this research it is concluded that the climate in the Agricultural Experiment Station has an effect on postpartum mortality in the Hereford breed. In addition, the radiation and and humidity correlate with the loss of pregnant bellies of Hereford and Braford under these environmental conditions.

\section{ACKNOWLEDGMENTS}

The authors thank the National Institute of Agricultural Technology of Argentina for the facilities provided to carry out this research.

\section{REFERENCES}

ARIAS R, Meyer L, Sánchez C. 2008. Factores climáticos que afectan el desempeño reproductivo del ganado bovino de carne y leche (Tesis Licenciatura). Tamuco, Chile: Univ Católica.

ARROYO AJJ, Elizondo SJA. 2014. Prevalencia de falla en la transferencia de inmunidad pasiva en terneras de lechería. Agronomía Mesoamericana. 25(2):279-285. http://revistas.ucr.ac.cr/index.php/agromeso/issue/view/1602

BURROW HM, Prayaga KC.2004. Correlated responses in productive and adaptive traits and temperament following selection for growth and heat resistance in tropical beef cattle. Livestock Production Science. 86(1-3):143-161. http://dx.doi.org/10.1016/j.livprodsci.2003.06.001

COL BA, Kadzere CT, Murphy MR. 2002. Heat stress in lactating dairy cows: a review. Livestock Production Science. 77(1):59-91. http://dx.doi.org/10.1016/S03016226(01)00330-X

CÓRDOVA IA, Murillo MA, Castillo JH. 2009. Efecto de factores climáticos sobre la conducta reproductiva bovina en los trópicos. Una revisión. Revista electrónica de Veterinaria. 11(1):1-12. http://www.veterinaria.org/revistas/redvet/n010110/011006.pdf

DA SILVA RG. 2006. Weather and climate and animal production. En: Update of the guide to agricultural meteorological practices. WMO-No.134. http://www.agrometeorology.org/files-folder/repository/

DE LUCA LJ. Aborto bovino; causas, frecuencia, etiopatogenia, inmunidad. 2002. (Consultada en 2016/09/15). http://www.produccionbovina.com/sanidad_intoxicaciones_metabolicos/enfermedades_r eproduccion/37-aborto_bovino.pdf

DOBSON H, Smith RF. 2000. What is stress, and how does it affect reproduction? Animal Reproduction Science. 60-61(1):743-752. http://dx.doi.org/10.1016/S03784320(00)00080-4 
DRAGHI MG, Soni CA, Beckwith B, Zurbriggen MA, Homse AC, Rochinotti D, Rizzi CA, Alcaraz EL, Caspe SG, Ramírez JC, Pereira M, Biotti GM, Ramírez LM, Sosa CG. 2007. Estudio de las distintas causas de mortalidad perinatal en bovinos en el Nordeste Argentino. Serie Técnica. 40(1):1-38. http://inta.gob.ar/sites/default/files/script-tmp-inta_mortalidad_perinatal_bovinos.pdf

ESCOBAR J, Huertas F. 2005. Influencias climáticas sobre la reproducción en Ganado Holstein. Medellin, Colombia. V Reunión ALPA, G-70.

FABER SN, Faber NE, McCauley TC, Ax RL. 2005. Effects of colostrum ingestion on lactational performance. Professional Animal Science. 21(4):420-425. http://dx.doi.org/10.15232/S1080-7446(15)31240-7

GRANJA SYT, Ribeiro JC, Toro GD, Rivera CL, Machado M, Manrique AA. 2012. Acidosis ruminal en bovinos lecheros: implicaciones sobre la producción y la salud animal. Revista electrónica de Veterinaria. 13(1):1-11. http://www.veterinaria.org/revistas/redvet/n040412/041210.pdf

HANSEN PJ, Drost M, Rivera RM, Paula-Lopes FF, Al-Katanani YM, Krininger CE, Chase CC. 2001. Adverse impact of the heat stress on embryo production: causes and strategies for mitigation. Theriogenology. 55(1):91-103. http://www.theriojournal.com/article/S0093$691 \times(00) 00448-9 /$ pdf

INFOSTAT. 2014. Software estadístico InfoStat. Facultad de Ciencias Agropecuarias, Universidad Nacional de Córdoba, Argentina.

INGRAHAM RR, Gillette D, Wagner W. 1974. Relationship of temperature and humidity to conception rate of Holstein cows in subtropical climate. Journal of Dairy Science. 57(4):476-481. DOI: http://dx.doi.org/10.3168/jds.S0022-0302(74)84917-9

LARA JE, Bottegal DN, Zimerman M, Suarez AF, Ballón M, Martínez-Calsina L. 2014. Condiciones ambientales y consumo de agua en un sistema silvopastoril comparado con un sistema pastoril. Revista Argentina de Producción Animal. 34(Suppl 1):213-290. http://ppct.caicyt.gov.ar/index.php/rapa/article/view/5380/4996

LÓPEZ H, Satter LD, Wiltbank MC. 2004. Relationship between level of milk production and estrous behavior of lactating dairy cows. Animal Reproduction Science. 81(3-4):209223. doi:10.1016/j.anireprosci.2003.10.009

MANSILLA V. 2006. Estudio preliminar de algunas variables climáticas sobre la eficiencia reproductiva en vacas Holstein Friesian en la provincia de nuble (Tesis de Licenciatura). Concepción, Chile: Univ de Concepción.

MONTIEL F, Ahuja C. 2005. Body condition and suckling as factors influencing the duration of postpartum anestrus in cattle: a review. Animal Reproduction Science. 85(12):1-26. doi:10.1016/j.anireprosci.2003.11.001 
NIENABER JA, Hahn GL, Brown-Brandl TM, Eigenberg RA. 2003. Heat stress climatic conditions and the physiological responses of cattle. 5th International Dairy Housing Proceedings of the 29-31 January Conference, Fort Worth Texas, USA. ASAE publication No 701P0203, Pp 255-262.

PIRES AV, Ribeiro CV, Mendes CQ. 2011. Aspectos nutricionais relacionados à reprodução. Págs. 537-563 En: Berchielli TT, Pires VA, De Oliveira SM. Nutrição de ruminantes ( $2^{\mathrm{a}}$ edição), Jaboticabal: FUNEP.

RENAUDEAU D. 2005. Effects of short-term exposure to high ambient temperature and relative humidity on thermoregulatory responses of European (Large White) and Caribbean (Creole) restrictively-fed growing pigs. Animal Research. 54(2):81-93. https://doi.org/10.1051/animres:2005005

RIVERA-SUAREZ F, Madrid-Buri N, González-Stagnaro C, Sandoval-Sánchez L. 2006. Efecto del índice humedad-temperatura sobre la tasa de fertilidad en vacas mestizas. Revista Científica. http://www.saber.ula.ve/bitstream/123456789/27440/2/articulo4.pdf 11(1):30-34.

ROMÁN PH. 2008. Efecto del estrés térmico sobre la fertilidad del Ganado bovino. Veracruz, México. P.265-288.

SARTORI R. 2006. Mortalidad Embrionaria en Bovinos Lecheros. Brazil: Embrapa Recursos Genéticos e Biotecnologia. http://www.syntexar.com/descargas/4Espanol\%20Sartori-Morte\%20embr.pdf

URIBE VLF, Oba E, Brasil LHA, Souza FN, Wechsler FS. 2001. Efeitos do estresse termico nas concentracoes plasmaticas de progesterona $\left(P_{4}\right)$ e estradiol 17-b $\left(E_{2}\right)$ e temperatura retal em cabras da raça Pardo Alpina. Revista Brasileña de Zootecnia. 30(2):388-393. http://www.scielo.br/pdf/rbz/v30n2/5479.pdf 